\title{
HIGH YIELD ROUTES TO \\ HEXA(DIMETHYLSILYLOXY)SILSESQUIOXANE AND HEXA(BROMODIMETHYLSILYLOXY)SILSESQUIOXANE
}

\author{
Philip G. Harrison*, Rainer Kannengiesser and Christopher J. Hall \\ Department of Chemistry, University of Nottingham, University Park, Nottingham NG7 2RD, UK
}

\section{Summary}

Convenient high yield routes to both hexa(dimethylsilyloxy)silsesquioxane, $\mathrm{Si}_{6} \mathrm{O}_{15}\left(\mathrm{SiMe}_{2} \mathrm{H}\right)_{6}$, and hexa(bromodimethylsilyloxy)silsesquioxane, $\mathrm{Si}_{6} \mathrm{O}_{15}\left(\mathrm{SiMe} \mathrm{Br}_{6}\right.$, via the ionic salt $\left(\mathrm{NEt}_{4}\right)_{6}\left\{\mathrm{Si}_{6} \mathrm{O}_{15}\right\} .30 \mathrm{H}_{2} \mathrm{O}$ are described.

\section{Introduction}

Examination of the structures adopted by zeolites and related materials shows that the channels and cavities comprise closed polyhedra made up of silicon/aluminium and oxygen atoms. The smallest such unit observed in zeolites is the cubane [ $\mathrm{Si}_{8} \mathrm{O}_{12}$ ] cage (I) although much larger polyhedra also occur. Closed vertex spherosilicates of the general formula $\left(\mathrm{XSiO}_{1.5}\right)_{\mathrm{n}}(\mathrm{n} \geq 6 ; \mathrm{X}=$ reactive functional group) are ideal candidates as precursors for the construction of three-dimensional polymeric architectures $[1,2]$. Whereas the cubane [Si $\left.\mathrm{S}_{8} \mathrm{O}_{12}\right]$ cage is isotropic, the [ $\left.\mathrm{Si}_{6} \mathrm{O}_{9}\right]$ cage is anisotropic and should, therefore, lead to microporous polymeric materials with rather different characteristics. Unfortunately, suitable high yield routes to molecular precursors possessing these frameworks are not available. In this paper we report convenient, high yield routes to both hexa(dimethylsilyloxy)silsesquioxane, $\mathrm{Si}_{6} \mathrm{O}_{15}\left(\mathrm{SiMe}_{2} \mathrm{H}\right)_{6}$, and hexa(bromodimethylsilyloxy)silsesquioxane, $\mathrm{Si}_{6} \mathrm{O}_{15}\left(\mathrm{SiMe}_{2} \mathrm{Br}\right)_{6}$, via the ionic salt $\left(\mathrm{NEt}_{4}\right)_{6}\left\{\mathrm{Si}_{6} \mathrm{O}_{15}\right\}$.

\section{Results and discussion}

The first double three ring silicate cage compounds, $\left(\mathrm{CH}_{3}\right)_{6} \mathrm{Si}_{6} \mathrm{O}_{9}$ and $\left(\mathrm{C}_{2} \mathrm{H}_{5}\right)_{6} \mathrm{Si}_{6} \mathrm{O}_{9}$, were first synthesised in 1955 by Sprung and Guenther $[3,4]$, with the homologous compounds, $\left(\mathrm{C}_{7} \mathrm{H}_{15}\right)_{6} \mathrm{Si}_{6} \mathrm{O}_{9},\left(\mathrm{C}_{8} \mathrm{H}_{17}\right)_{6} \mathrm{Si}_{6} \mathrm{O}_{9}$, (iso- $\left.\mathrm{C}_{9} 19\right)_{6} \mathrm{Si}_{6} \mathrm{O}_{9}[5,6]$, $\left(\mathrm{C}_{6} \mathrm{H}_{11}\right)_{6} \mathrm{Si}_{6} \mathrm{O}_{9}[7,8]$, and $\left(\mathrm{C}_{6} \mathrm{H}_{5}\right)_{6} \mathrm{Si}_{6} \mathrm{O}_{9}[9,10]$ being synthesised in the following years. The general method of preparation is by the hydrolysis of the corresponding alkyltrichlorosilane or alkyl(trisalkoxy)silane. In 1970, Smolin [11] synthesised and determined the $\mathrm{X}$-ray structure of the $\left\{\mathrm{Si}_{6} \mathrm{O}_{15}{ }^{6-}\right\}$ anion as the $\left[\mathrm{Ni}(\mathrm{en})_{3}\right]^{2+}$ salt by reacting an ethylenediamine solution of nickel hydroxide with a $2.5 \%$ solution of silica in ethylenediamine. The structure showed that the cage is distorted so that most of the OSiO bond angles are very close to the tetrahedral angle.

In the seventies many studies of acidified sodium monosilicate solutions by ${ }^{29} \mathrm{Si}$ gave evidence that double three ring silicates are also present in these systems [12-18]. Subsequent investigations of silicate solutions containing the tetraethylammonium cation showed that this had a stabilizing effect on the double three ring silicate system [19-23]. It was found that using the tetraethylammonium cation in a silicate solution favours the formation of doublt three ring silicates to more than $95 \%$ if the optimum concentration range of $\mathrm{Si}$ and the optimum Si: $\left\{\mathrm{NEt}_{4}\right\}$ ratio is chosen [19]. Similar results were also obtained by Groenen [24] investigating water/DMSO solutions of different tetraaethylammonium/silicate ratios. The trimethylsilylester of the $\left\{\mathrm{Si}_{6} \mathrm{O}_{15}{ }^{6-}\right\}$ anion, $\left[\left(\mathrm{CH}_{3}\right)_{3} \mathrm{Si}\right]_{6} \mathrm{Si}_{6} \mathrm{O}_{15}$, has been obtained and structurally characterised by Hoebbel [25].

The preparation of the $\left\{\mathrm{Si}_{6} \mathrm{O}_{15}{ }^{6-}\right\}$ anion as the tetraethylammonium salt has previously been described by Hoebbel [26] by reacting silica gel with an aqueous $\mathrm{NEt}_{4} \mathrm{OH}$ 
solution (N:Si ratio 1:1) for 3 days from which crystalline $\left(\mathrm{NEt}_{4}\right)_{6}\left\{\mathrm{Si}_{6} \mathrm{O}_{15}\right\} .57 \mathrm{H}_{2} \mathrm{O}$ could be recovered by crystallisation. A more convenient and shorter preparation of $\left(\mathrm{NEt}_{4}\right)_{6}\left\{\mathrm{Si}_{6} \mathrm{O}_{15}\right\}$ (I) is by the hydrolysis of $\mathrm{Si}(\mathrm{OEt})_{4}$ in an aqueous tetraethylammonium hydroxide solution (N:Si ratio 1:1):

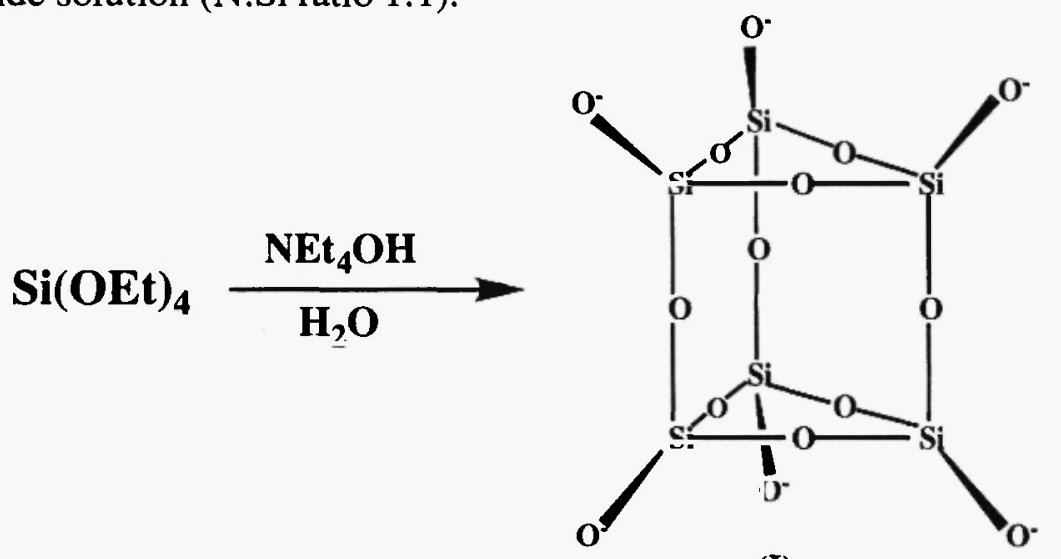

(I)

The product was obtained in near quantitative yield as a polyhydrate after removal of the water and the ethanol formed. The ${ }^{29} \mathrm{Si} \mathrm{nmr} \mathrm{spectrum} \mathrm{(saturated} \mathrm{D}_{2} \mathrm{O}$ solution) exhibits a single resonance at $-87.48 \mathrm{ppm}$ due to the silicon atoms of the $\left\{\mathrm{Si}_{6} \mathrm{O}_{15}\right\}$ cage (cf. $c a$. $-88 \mathrm{ppm}[19]$ ), with only small peaks at $-69 \mathrm{ppm}$ due to a small amount of monosilicate (ca. $2-3 \%),-77.32$ due to disilicate (ca. $2 \%$ ), and $-79.80 \mathrm{ppm}$ due to the cyclic $\left\{\mathrm{Si}_{3} \mathrm{O}_{9}\right\}$ silicate (ca. 2-3\%).

The quite strained $\left\{\mathrm{Si}_{6} \Theta_{15^{6-}}\right\}$ cage is labile towards hydrolysis and condensation reactions. However, this may be overcome by silylation with dimethylchlorosilane in a dimethylformamide/heptane mixture giving the hexa(dimethylsilyloxo)-substituted cage $\mathrm{Si}_{6} \mathrm{O}_{15}\left(\mathrm{SiMe}_{2} \mathrm{H}\right)_{6}$ (II) which is significantly less labile and is very soluble in organic solvents:

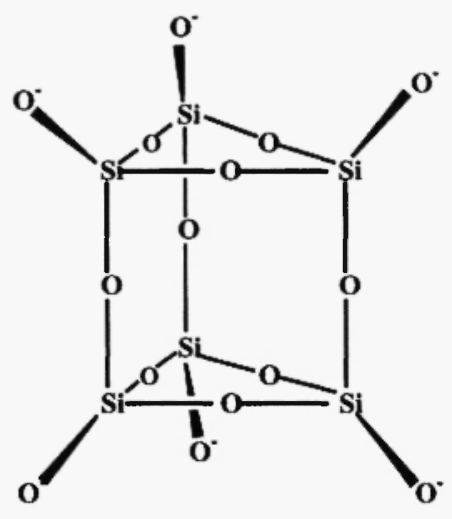

(I)

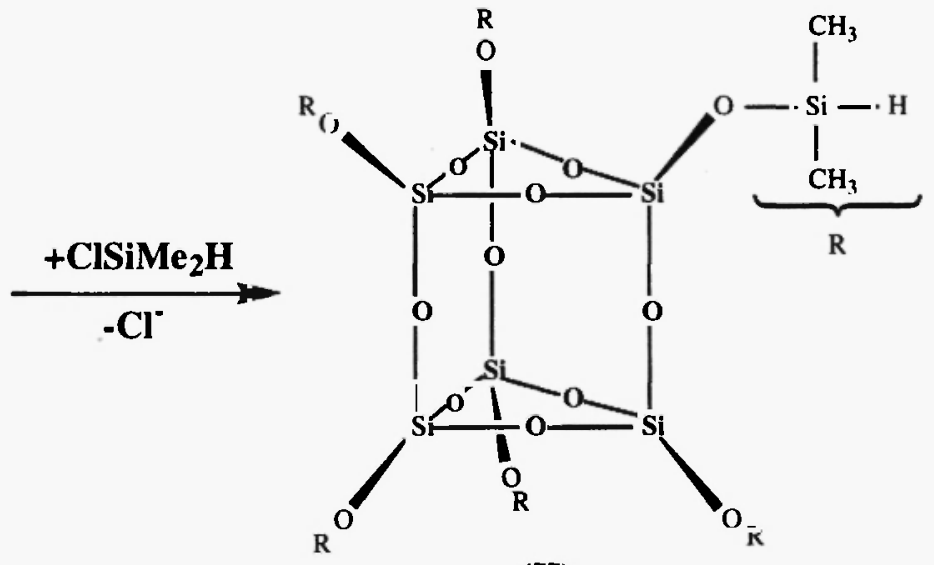

(II)

The nmr spectra confirm the identity of the silylated cage. The ${ }^{1} \mathrm{H}$ nmr spectrum of (II) exhibits a septet centred at $4.73 \mathrm{ppm}$ for the $\mathrm{Si}-\mathrm{H}$ hydrogens due to coupling with six methyl hydrogens and a doublet at $0.255 \mathrm{ppm}$ flanked by satellites due to ${ }^{29} \mathrm{Si}$ coupling $\left\{{ }^{2} \mathrm{~J}\left({ }^{29} \mathrm{Si}-{ }^{1} \mathrm{H}\right)=c a .7 \mathrm{~Hz}\right\}$ in the ratio $1: 6\left\{{ }^{3} \mathrm{~J}\left({ }^{1} \mathrm{H}-{ }^{1} \mathrm{H}\right)=2.5 \mathrm{~Hz}\right\}$. The ${ }^{29} \mathrm{Si} \mathrm{nmr}$ spectrum exhibits a singlet resonance at $-98.94 \mathrm{ppm}$ due to the cage silicon atoms and a doublet of partially resolved septets for the $S i \mathrm{Me}_{2} \mathrm{H}$ silicon atoms centred at $0.31 \mathrm{ppm}$ due to coupling with both types of hydrogen atom $\left\{{ }^{1} \mathrm{~J}\left({ }^{29} \mathrm{Si}-{ }^{1} \mathrm{H}\right)=210.7 \mathrm{~Hz},{ }^{2} \mathrm{~J}\left({ }^{29} \mathrm{Si}^{1} \mathrm{H}\right)=7.5 \mathrm{~Hz}\right\}$. The ${ }^{29} \mathrm{Si}$ solid state $\mathrm{nmr}$ spectrum of $\mathrm{Si}_{6} \mathrm{O}_{15}\left(\mathrm{SiMe}_{2} \mathrm{H}\right)_{6}$, however, is much more complex. The 
resonance for the cage silicon atoms, which is a single resonance in the ${ }^{29} \mathrm{Si}$ solution $\mathrm{nmr}$ spectrum, becomes five resonances at $-98.32,-98.74$. $-99.15,-99.88$ and $-100.54 \mathrm{ppm}$ in the solid state spectrum, indicative of considerable distortion of the cage due to crystal packing effects. The $\mathrm{SiMe}_{2} \mathrm{H}$ silicon atoms show four resonances at $0.43,-0.06,-0.83$ and $-1.83 \mathrm{ppm}$. The undecoupled ${ }^{13} \mathrm{C}$ solution $\mathrm{nmr}$ spectrum shows the expected coupling of the methyl and $\mathrm{Si}-\mathrm{H}$ hydrogens with the methyl carbon atoms to give a quartet of doublets at $\delta=0.025 \mathrm{ppm}\left\{{ }^{2} \mathrm{~J}\left({ }^{13} \mathrm{C}-{ }^{1} \mathrm{H}\right)=11.95 \mathrm{~Hz},{ }^{1} \mathrm{~J}\left({ }^{13} \mathrm{C}-{ }^{1} \mathrm{H}\right)=119.5 \mathrm{~Hz}\right\}$. In contrast, the ${ }^{13} \mathrm{C}$ solid state $\mathrm{nmr}$ spectrum exhibits only a single peak at $0.85 \mathrm{ppm}$ for the $\mathrm{Si}\left(\mathrm{CH}_{3}\right)_{2} \mathrm{H}$ methyl group carbon atoms.

In the infrared $\mathrm{Si}_{6} \mathrm{O}_{15}\left(\mathrm{SiMe}_{2} \mathrm{H}\right)_{6}$ exhibits characteristic $v(\mathrm{Si}-\mathrm{H}), \mathrm{v}_{\text {anti }}(\mathrm{Si}-\mathrm{O})$, and $\delta(\mathrm{OSiO})$ vibrations at 2142,1174 and 1095 , and $551 \mathrm{~cm}^{-1}$, respectively. The mass spectrum is very simple with clusters of peaks at $\mathrm{m} / \mathrm{e}=762( \pm 2)$ due to the parent ion with gain and loss of up to two hydrogens, and at $\mathrm{m} / \mathrm{e}=746( \pm 2)$ due to loss of a methyl group from these fragments. Other minor peaks due to the loss of exocage methylsiloxy fragments are also observed, however none due to the fragmentation of the cage structure itself are apparent. The strong peaks at m/e 74 and 60 are due to $\mathrm{Me}_{2} \mathrm{SiH}_{2}{ }^{+}$and $\mathrm{Me}_{3} \mathrm{SiH}^{+}$, respectively.

The hydrido cage $\mathrm{Si}_{6} \mathrm{O}_{15}\left(\mathrm{SiMe}_{2} \mathrm{H}\right)_{6}$ may be converted to the corresponding hexabromo compound $\mathrm{Si}_{6} \mathrm{O}_{15}\left(\mathrm{SiMe}_{2} \mathrm{Br}\right)_{6}$ (III) by the catalytic bromination by allyl bromide both as solvent and reagent at $60^{\circ}$ for $3.5 \mathrm{~h}$ under nitrogen using $\mathrm{Rh}(\mathrm{acac})_{3}$ as catalyst:

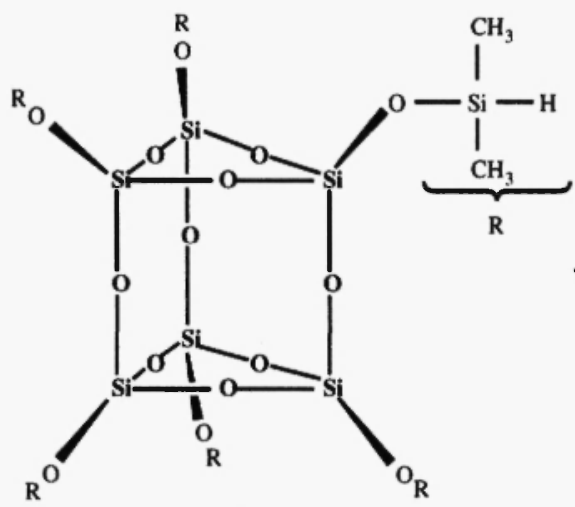

(II)

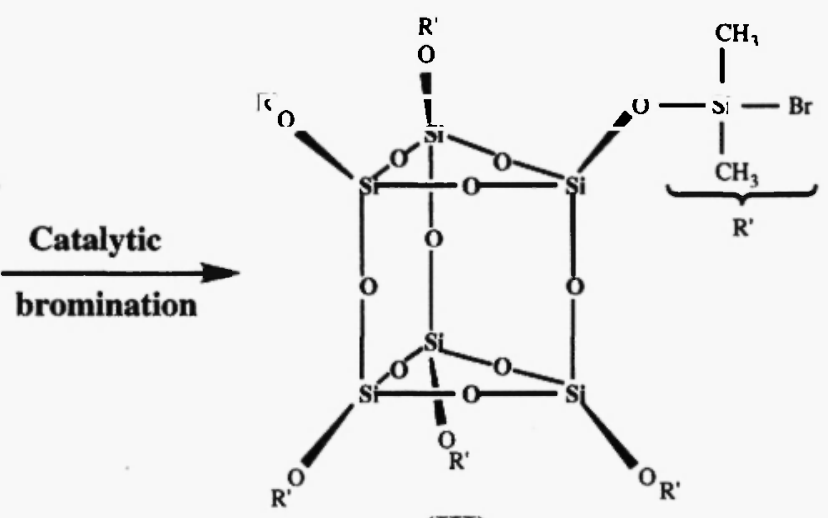

(III)

As with (II), (III) may be fully characterised by $\mathrm{nmr}$. The ${ }^{1} \mathrm{H} \mathrm{nmr}$ spectrum exhibits only a single resonance at $0.69 \mathrm{ppm}$ for the methyl hydrogens, and no resonance is observed at $4.73 \mathrm{ppm}$ indicating that all the $\mathrm{Si}_{6} \mathrm{O}_{15}\left(\mathrm{SiMe}_{2} \mathrm{H}\right)_{6}$ has been consumed. The ${ }^{29} \mathrm{Si}$ solid state spectrum exhibits a singlet resonance at $-100.94 \mathrm{ppm}$ for the cage silicon atoms and also a partially resolved septet centred at $6.59 \mathrm{ppm}$ for the $S i \mathrm{Me}{ }_{2} \mathrm{Br}$ silicon atoms $\left\{{ }^{2} \mathrm{~J}\left({ }^{29} \mathrm{Si}-{ }^{1} \mathrm{H}\right)=\right.$ $7.5 \mathrm{~Hz}\}$. The ${ }^{13} \mathrm{C}$ spectrum exhibits the expected quartet at $5.45 \mathrm{ppm}\left\{{ }^{1} \mathrm{~J}\left({ }^{13} \mathrm{C}-{ }^{1} \mathrm{H}\right)=\right.$ $122.0 \mathrm{~Hz}$. In the infrared, the characteristic $v(\mathrm{Si}-\mathrm{H})$ band of $\mathrm{Si}_{6} \mathrm{O}_{15}\left(\mathrm{SiMe}_{2} \mathrm{H}\right)_{6}$ is completely absent, and the spectrum exhibits $\mathrm{v}(\mathrm{Si}-\mathrm{O})_{\text {anti }}$ bands at 1121,1071 and $1020 \mathrm{~cm}^{-1}$ and a $\delta(O S i O)$ band at $524 \mathrm{~cm}^{-1}$ A mass spectrum could not be obtained because of the very high molecular mass.

\section{Experimental}

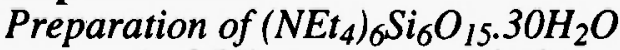

A $35 \%$ aqueous solution of $\mathrm{NEt}_{4} \mathrm{OH}(40 \mathrm{ml}, 95.2 \mathrm{mmol})$ was placed in a polyethylene bottle, followed by $\mathrm{Si}(\mathrm{OEt})_{4}(20 \mathrm{ml}, 89.6 \mathrm{mmol})$ and stirred overnight. The solvent was reduced under vacuum to give $25.6 \mathrm{~g}(99.1 \%)$ of $\left(\mathrm{NEt}_{4}\right)_{6} \mathrm{Si}_{6} \mathrm{O}_{15} .30 \mathrm{H}_{2} \mathrm{O}$ (Found: $\mathrm{C}, 33.21 ; \mathrm{H}, 10.69 ; \mathrm{N}, 4.72 \%$. $\mathrm{C}_{48} \mathrm{H}_{180} \mathrm{~N}_{6} \mathrm{Si}_{6} \mathrm{O}_{45}$ requires: $\mathrm{C}, 33.31 ; \mathrm{H}, 10.51$; $\mathrm{N}, 4.86 \%$ ). 
Preparation of $\mathrm{Si}_{6} \mathrm{O}_{15} / \mathrm{SiMe}_{2} \mathrm{H}_{6}$

To a vigourously stirred mixture of dimethylchlorosilane $(100 \mathrm{ml}, 0.92 \mathrm{~mol})$, heptane $(500 \mathrm{ml})$ and dimethylformamide $(200 \mathrm{ml})$ cooled with an ice bath was added $\left(\mathrm{NEt}_{4}\right)_{6} \mathrm{Si}_{6} \mathrm{O}_{15} .30 \mathrm{H}_{2} \mathrm{O}(14 \mathrm{~g}, 8.07 \mathrm{mmol})$ over a period of $c a .30 \mathrm{~min}$. After addition of all the $\left(\mathrm{NEt}_{4}\right)_{6} \mathrm{Si}_{6} \mathrm{O}_{15} \cdot 30 \mathrm{H}_{2} \mathrm{O}$ the mixture was stirred for an additional $30 \mathrm{~min}$ and then allowed to warm to room temperature. Ice-water (11) was added and the mixture stirred for $15 \mathrm{~min}$. The upper organic layer was separated and washed three times with water $(150 \mathrm{ml})$ until neutral. The organic solvent was removed under reduced pressure and the colourless residue recrystallised from acetonitrile to give $\mathrm{Si}_{6} \mathrm{O}_{15}\left[\mathrm{SiMe}_{2} \mathrm{H}\right]_{6}(3.1 \mathrm{~g}, 50.4 \%)$ M.p. $239^{\circ}$. (Found: $\mathrm{C}, 18.82 ; \mathrm{H}, 5.85 \% \quad \mathrm{C}_{12} \mathrm{H}_{42} \mathrm{Si}_{12} \mathrm{O}_{15}$ requires: $\mathrm{C}, 18.87 ; \mathrm{H}, 5.56 \%$ ). Infrared data: 2963w, 2922vw, 2142m, 1256m, 1174m,sh, 1095s, 899s, 834w, 768w, $755 \mathrm{w}, \mathrm{sh}, 725 \mathrm{vw}, \mathrm{sh}, 648 \mathrm{vw}, 627 \mathrm{vw}, 551 \mathrm{~m} \mathrm{~cm}^{-1}$.

Preparation of $\left.\mathrm{Si}_{6} \mathrm{O}_{15} / \mathrm{SiMe}_{2} \mathrm{Br}\right]_{6}$

A solution of $\mathrm{Si}_{6} \mathrm{O}_{15}\left[\mathrm{SiMe}_{2} \mathrm{H}\right]_{6}(2.5 \mathrm{~g}, 3.27 \mathrm{mmol})$, dry, oxygen-free allyl bromide $(10 \mathrm{ml})$ and $\mathrm{Rh}(\mathrm{acac})_{3}(\mathrm{acac}=$ acetylacetonate $)(0.15 \mathrm{mg})$ was heated at $60^{\circ}$ for $3.5 \mathrm{~h}$ under a nitrogen atmosphere. The allyl bromide was removed under reduced pressure to give $\mathrm{Si}_{6} \mathrm{O}_{15}\left[\mathrm{SiMe}_{2} \mathrm{Br}\right]_{6}(4.02 \mathrm{~g}, 98.9 \%)$ M.p. 298 . (Found: C, 11.47; H, 3.07\% $\mathrm{C}_{12} \mathrm{H}_{36} \mathrm{Br}_{6} \mathrm{Si}_{12} \mathrm{O}_{15}$ requires: $\mathrm{C}, 11.65 ; \mathrm{H}, 2.94 \%$ ). Infrared data: $2961 \mathrm{w}, 2920 \mathrm{vw}$, $1260 \mathrm{~m}, 1121 \mathrm{~m} \mathrm{sh}, 1071 \mathrm{~s}, 1020 \mathrm{~m} \mathrm{sh}, 895 \mathrm{vw}$ sh, $851 \mathrm{~m}, 818 \mathrm{~m}, 801 \mathrm{~m}, 744 \mathrm{vw}, 698 \mathrm{vw}$, $676 \mathrm{w}, 658 \mathrm{vw} \mathrm{sh}, 608,592 \mathrm{vw} \mathrm{sh}, 524 \mathrm{w} \mathrm{cm}-1$.

\section{References}

1. D. Hoebbel, K. Endres, T. Reinert and I. Pitsch, J. Non-Cryst. Solids, 1994, 176, 179.

2. P.G. Harrison and R. Kannengiesser, J. Chem. Soc., Chem. Commun., 1996, 415.

3. M.M. Sprung and F.O. Guenther, J. Am. Chem. Soc., 1955, 77, 3990, 3996.

4. K.A. Andrianov and B.A. Izmailor, Zh. Obshch. Khim., 1966, 36, 341; 1976, 46, 329.

5. K.A. Andrianov and B.A. Izmailor, J. Organometal. Chem., 1967, 3, 435.

6. J.F. Brown, J. Am. Chem. Soc., 1965, 87, 4317.

7. F.J. Feher, D.A. Newman and J.F. Walzer, J. Am. Chem. Soc., 1989, 111, 1741.

8. K.A. Andrianov and V.A. Odinets, Izv. Akad. Nauk SSSR, Otd. Khim. Nauk, $1959,460$.

9. K.A. Adrianov and A.A. Zhdanov, Plastmassy, 1962, 7, 24.

10. Yu. I. Smolin, Sov. Phys. Crystallogr., 1970, 15, 23.

11. D. Hoebbel and W. Wieker, Z. anorg. allg. Chem., 1973, 400, 148.

12. G. Engelhardt, D. Zeigan, H. Jancke, D. Hoebbel and W. Wieker, Z. anorg. allg. Chem., 1975, 418, 17.

13. G. Engelhardt, H. Jancke, D. Hoebbel and W. Wieker, Z. Chem., 1974, 14, 109.

14. D. Hoebbel, Z. anorg. allg. Chem., 1975, 414, 289.

15. H.C. Marsmann, Z. Naturforsch., 1974, 29b, 495.

16. R.O. Gould, B.M. Lowe and N.A. McGilb, J. Chem. Soc., Chem. Commun., $1974,720$.

17. D. Hoebbel , G. Garzo and G. Engelhardt, Z. anorg. allg. Chem., 1979, 450, 5.

18. D. Hoebbel , G. Garzo, G. Engelhardt, R. Ebert, E. Lippmaa and M. Alla, Z. anorg. allg. Chem., 1980, 465, 15.

19. D. Hoebbel , A. Vargha, B. Falke and G. Engelhardt, Z. anorg. allg. Chem., 1985, 521,61 .

20. R.K. Harris and C.T.G. Knight, J. Mol. Struct., 1982, 78, 273.

21. K.J. Carrell, A.F. Masters and K.G. Wilshier, Zeolites, 1982, 2, 244.

22. Yu. I. Smolin, Kristallografia, 1984, 29, 712.

23. E.J.J. Groenen, A.G.T.G. Kortbeck, M. Mackay and O. Sudmeijer, Zeolites, $1986,6,403$. 
24. D. Hoebbel, G. Engelhardt, A. Samoson, K. Ujszaszy, Yu. I. Smolin, Z. anorg. allg. Chem., 1987, 552, 236.

25. D. Hoebbel, G. Garzo, G. Engelhardt, R. Ebert, E. Lippmaa and M. Alla, Z. anorg. allg. Chem., 1980, 465, 15.

Received: October 24, 1996 - Accepted: November 18, 1996 " Accepted in revised camera-ready format: December 2, 1996 
